\author{
Margarita BOGDANOVA, \\ Evelina PARASHKEVOVA, \\ Mariela STOYANOVA
}

\title{
AGILE PROJECT MANAGEMENT IN PUBLIC SECTOR - METHODOLOGICAL ASPECTS
}

\begin{abstract}
One of the current approaches to improving business organizations is agile project management. It emerged in the software industry in 2001, but gradually entered other, non-software industries. However, the transfer of the approach to the public sector requires a specific transformation of the agile methodology, insofar as the two sectors are radically different. The public sector is predetermined by regulations, insufficiently oriented towards service users, bureaucratized and hierarchically organized. All this is a barrier to agile project management that aims at providing project team autonomy, frequent and honest feedback to clients and other stakeholders, flexibility of project scope, etc. The aim of the article is to present a conception of a methodology for agile project management in the public sector and to discuss the issues related to its implementation in governmental organizations.
\end{abstract}

(C) Margarita Bogdanova, Evelina Parashkevova, Mariela Stoyanova, 2020.

Bogdanova Margarita, Professor, Ph.D., Tsenov Academy of Economics - Svishtov, Bulgaria. Email: m.bogdanova@uni-svishtov.bg ORCID: 0000-0003-0558-5274

Parashkevova Evelina, Head Assist. Professor, Ph.D., Tsenov Academy of Economics - Svishtov, Bulgaria. Email: e.parashkevova@uni-svishtov.bg

Stoyanova Mariela, Assist. Professor, Ph.D., Tsenov Academy of Economics - Svishtov, Bulgaria. Email: m.stoyanova@uni-svishtov.bg ORCID: 0000-0003-2849-288X. 


\section{Key words:}

Agile project management, public administration, methodology implementation, «non-software» industries, governmental organizations.

JEL: H11, H43, H83.

\section{Literature review and the problem statement}

Agile project management emerges in response to several major problems in the work of the IT sector (Beck 2001). Generally, they are associated with increasing customer complaints, breach of contracted budgets and duration, which is why it is necessary to constantly conclude annexes for extension of time, changes in scope, product specifications for the project, etc. In general, less than $1 / 3$ of the projects are implemented successfully (Hass 2007), which is a powerful signal for systematic errors in their management. It is becoming increasingly clear that the traditional project management approach applied since the second half of the 20th century is ineffective.

The traditional approach applied in public sector organizations is even less successful. With them, the scope of projects is clearly defined, emphasizing highly controlled processes, strictly kept documentation and the high level of accountability. In objective terms, these are all positive features. However, they have negative consequences in a more dynamic external and internal design environment. Through the prism of public sector project implementation, they reflect in difficult team communication due to high hierarchy and excessive bureaucratization of project processes in the pursuit of enhancing control and accountability.

The conceptual differences that agile thinking offers represent the inversion of the manager's triangle. The differences can be seen graphically in Figure 1.

In the pursuit of more added value and flexible solutions, agile project management is governed by four basic principles that have become popular in Agile Manifesto: (Taymor 2017):

- Investing in people and relationships between them is a priority over detailed process scheduling; 
Figure 1

Differences between traditional and agile project management

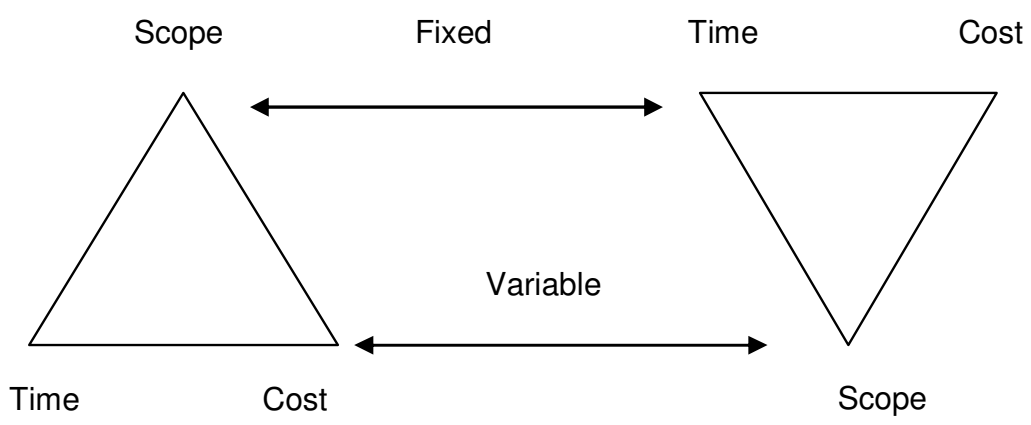

Traditional project management

Agile project management

Source: Owen, R., Koskela L., Henrich G., Codinhoto R. (2006).

- The final outcome of a project is more important than generating comprehensive implementation documentation;

- Focusing on customer interaction and feedback is more important than the pursuit of comprehensive legal regulation;

- The need to respond to changes is far more essential for achieving the main goals than the strict adherence to plans.

The fundamental principle of agile management, which distinguishes it from the traditional one, is the desire to add value at every stage of implementation, in a creative and innovative way. (Agile Project Management QuickStart Guide 2014). In this regard, limitations accompanying the traditional approach are in contrast to the process open to change, which is typical for the agile approach.

In literature, the issue of whether the agile approach is applicable to public sector organizations has been partially studied, mainly in the field of providing digital services to internal and external users.

What is common in the studies of different authors are the reasons for the slow introduction of new methodologies in the public sector. According to experts from the Project Management Institute (Government Extension to the PMBOK® Guide Third Edition 2006), additional factors (beyond those in the business) that affect public sector organizations are: 
- Regulatory rules regarding the implementation of the managerial and socio-political responsibilities of participants;

- The need for a project team to always serve and reflect public interest.

A. Ribeiro and L. Domingues (2018) applied a case study method to a Portuguese governmental organization. The public sector, according to the authors, is more bureaucratic and there is greater resistance to change. This makes it difficult to introduce new methodologies and approaches to businesses.

A number of authors have reached a similar conclusion, such as Powner (2012), who studied the implementation of agile project management in the state and federal authorities in the USA, Kaczorowska (2015), Karaj and J. Little (2013).

It seems that while the volume of publications related to agile PM in the private sector is huge and steadily increasing, studies are too scarce on the public sector. It is also unclear what the outcomes are for organizations where the method is already being applied (Conforto et al. 2014).

A study conducted in 2016 (Wisitpongphan \& Khampachua 2016) identifies two major challenges in the implementation of agile methodologies:

- lack of involvement and participation of final users in a project;

- lack of flexibility to integrate requirements during the project development.

Although rarely, scientific reports on successful practices can be found in literature. A study conducted by the University of Seville (Torrecilla-Salinas et al. 2013) presented the outcomes of an agile methodology application (Scrum, in this case) in a public organization. A project planning and estimation technique was used and it was verified that the planned project outcomes were achieved in almost all cases precisely through the Scrum methodology, which is one of the agile methodologies.

Another study related to the banking sector, aiming to assess the conditions for applying an agile methodology in the public sector, concluded that there was no great preference for agile practices (Roses, Windmöller, \& do Carmo 2016).

Similar is the conclusion of the Russian researchers Altukhova, Vasileva and Slavin (2016). They studied public sector attitudes to agile project management application in Russia, but concluded that, unlike business organizations, the motivation for informal leadership was low in government offices, and selforganization and self-management were not developed. The authors considered these to be serious barriers to the introduction of agile project management, although it could still be possible under certain circumstances. 
Currently, a developed methodology for agile project management in the public sector does not exist. Therefore, this study could be a useful starting point in this regard for both theory and practice.

\section{The aim of the article}

The aim of the article is to present a conception of a methodology for agile project management in the public sector and to discuss the issues related to its implementation in governmental organizations.

\section{Methodology}

The research approach used to develop an agile project management methodology in the public sector is based on standard scientific methods, mainly of a qualitative nature.

A wide range of secondary sources of information - scientific publications, analyses, methodologies, guides, best practices and standards for agile project management, both in businesses and in the public sector have been studied. Through content analysis, Collects participant meanings, Focuses on a single concept or phenomenon and induction, basic trends in the development and application of agile project management methods.

On this basis, specific characteristics and special features of agile management methods are defined through deduction, methods of which are implemented through research synthesis in the basic principles of the structured methodology for agile project management in the public sector.

The specific character and normative regulation of the public sector activity necessitated the development of a technique that is inherently hybrid - a combination of conventional and agile project management. The scientific approach applied to synchronize these methodologies is related to the definition of key common ground and develops a rationale for mixing.

The iterative approach is the basis of the methodology for agile project management in the public sector. The method of analogy and comparative analysis is used to define the main limitations and preconditions that are part of the methodology. 


\section{Research findings}

The concept of agile project management methodology is based on the team approach through which specific roles are assigned. Roles are project positions that are different from project duties. Agile management is implemented through them. They are dynamic. The same person may perform different roles at different intervals of project implementation.

The roles created for the needs of agile project management methodology in the public sector are as follows:

Public owner of project outcomes - the head of a public sector organization within which the project is implemented and managed.

Team leader / Project owner - this is the person who usually performs leadership functions in the organization and provides the necessary organizational conditions for the successful implementation of a project.

Task owner - responsible for the outcomes of the task assigned. They carry out internal monitoring of the task and make decisions on changes after discussing them with the team.

A Person responsible for iteration/s - a team member responsible for executing the iteration assigned. Works independently or in a team. Maintains a close relationship with the task owner responsible for the iteration currently performed.

Ordinary team members - team members who perform iterations but are not responsible for them.

Agile management master/specialist - an administration official who has experience and knowledge in the field of agile project management. Their involvement in a team is solely to ensure the implementation of the agile methodology and to assist the team in the emergence of different issues with regard to agile project management.

A Member, external to the organization - representative/s of the stakeholders involved in the project team. They may perform any of the above roles except for the roles of a project owner and a public owner of project outcomes.

In order for the methodology to work, teams should have a limited staff of 3 to 9 people. Self-organization is key. Communication and coordination are facilitated, interaction is more efficient. Flexibility is ensured by the fact that team members have freedom while working, which in turn contributes to faster adaptation to changing external conditions. The team maintains optimum internal communication channels. 
The team learns while working, enhances products and/or services, as well as their work every subsequent cycle. Autonomous team decision-making, reducing the volume and complexity of tasks, iterations, fast feedback and selfcontrol are the basis of the methodology.

Agile project management is characterized by rapid iterative cycles of planning and development that allow a project team to constantly evaluate its work and receive immediate feedback from other team members and, if possible, from stakeholders. Iterations are based on simple planning, on defining requirements and designing solutions that are continuously conducted throughout project implementation.

The concept of project management methodology in public sector organizations is structured in three interrelated stages, which are cyclical: Stage 1. Preparing for agile project management; Stage 2. Implementing agile project management; Stage 3. Internal monitoring. The division of stages is indicative and aims to create a better organization for methodology implementation. For each stage, inputs and outputs as well as specific implementation steps are defined. Flowcharts are created to show the various stages of the methodology, as well as matrices of rights, responsibilities and allocated roles.

During Stage 1. Preparing for agile project management, a crossfunctional project team is formed. The team, on the basis of existing administration practices and the specifics of each individual project, has the autonomy to decide whether or not to apply agile management. Whenever possible, a representative of stakeholders and/or target groups is involved to ensure their participation. After its formation, the team holds a meeting to discuss and adopt rules for agile project management, including the tools that will be applied. The roles within the team are also assigned during this stage. The decisions made at this stage are not finite. They are changed when changing organization, the team, or in case of finding decisions ineffective and inoperative.

During Stage 2. Implementing agile project management, the team becomes familiar with the prepared project launch document. A list of requirements is prepared on this basis. The overall project work or activities are formulated as tasks. Each task is broken up into smaller parts - iterations. Each iteration and task is framed in an indicative timeline. Tasks are continuously prioritized and iterations for their execution are highlighted accordingly. Whenever possible, several iterations are performed simultaneously. An instrument for outcome measurement is determined for each task. Iterations are assigned throughout the process. In accordance with the adopted rules for agile project management, team meetings are held to discuss progress, problems and necessary changes. Various agile management tools are applied to improve overall coordination of iteration implementation and to facilitate communication and control. Adjustments are made and progress is reported. Minimum documentation is prepared to meet the financial requirements of the external audit and control bodies, and of legislation. Retrospective meetings are held to share lessons learned. A large number of steps are performed repeatedly, i.e. cyclically. 
Table 1

Responsibility matrix in Stage 1. Preparing for agile project management

\begin{tabular}{|c|c|c|c|c|c|c|}
\hline Step Role & $\begin{array}{l}\text { Project } \\
\text { owner }\end{array}$ & $\begin{array}{l}\text { Public } \\
\text { owner of } \\
\text { project } \\
\text { outcomes }\end{array}$ & $\begin{array}{l}\text { Task/s } \\
\text { owner }\end{array}$ & \begin{tabular}{|c|} 
A person \\
respon- \\
sible for \\
itera- \\
tion/s \\
\end{tabular} & $\begin{array}{l}\text { Agile man- } \\
\text { agement } \\
\text { master/ } \\
\text { specialist }\end{array}$ & $\begin{array}{l}\text { Ordinary } \\
\text { team } \\
\text { mem- } \\
\text { bers }\end{array}$ \\
\hline $\begin{array}{l}\text { Formation of a } \\
\text { cross- } \\
\text { functional pro- } \\
\text { ject manage- } \\
\text { ment team }\end{array}$ & $\mathrm{P} / \mathrm{I}^{*}$ & MD & Inf & Inf & C & Inf \\
\hline $\begin{array}{l}\text { Making deci- } \\
\text { sions on agile } \\
\text { project man- } \\
\text { agement in } \\
\text { administration }\end{array}$ & C & MD & Inf & Inf & $\mathrm{P} / \mathrm{I}$ & $\mathrm{P} / \mathrm{I}$ \\
\hline $\begin{array}{l}\text { Approval of a } \\
\text { team }\end{array}$ & $\mathrm{P} / \mathrm{I}$ & MD & Inf & Inf & Inf & Inf \\
\hline $\begin{array}{l}\text { Team meeting } \\
\text { to discuss the } \\
\text { rules of agile } \\
\text { project man- } \\
\text { agement }\end{array}$ & $\mathrm{P} / \mathrm{I}$ & $\mathrm{P} / \mathrm{I}$ & $\mathrm{P} / \mathrm{I}$ & $\mathrm{P} / \mathrm{I}$ & $\mathrm{P} / \mathrm{I} / \mathrm{C}$ & $\mathrm{P} / \mathrm{I}$ \\
\hline $\begin{array}{l}\text { Assigning roles } \\
\text { to the team }\end{array}$ & MD & $\mathrm{P} / \mathrm{Inf}$ & $\mathrm{P} / \mathrm{Inf}$ & $\mathrm{P} / \mathrm{Inf}$ & $\mathrm{P} / \mathrm{C}$ & $\mathrm{P} / \mathrm{Inf}$ \\
\hline
\end{tabular}

*Key: MD - makes decisions; P - participates; C - co-ordinates; I - implements; Inf - informs. Source: compiled by the authors.

Stage 3. Internal monitoring studies the project history. Within team meetings, iteration execution is reported and the level of achieving the progress indicators of individual tasks is periodically reported. Conformity checks are carried out and adjustment recommendations are made, including organizational ones. Monitoring is a tool for continuous adaptation and improvement. During one of the retrospective meetings, part of Stage 2, monitoring lessons shared within the organization through project stories are defined. 
Table 2

Responsibility matrix in Stage 2. Implementing agile project management

\begin{tabular}{|c|c|c|c|c|c|c|}
\hline Step Role & $\begin{array}{l}\text { Project } \\
\text { owner }\end{array}$ & $\begin{array}{l}\text { Public } \\
\text { owner of } \\
\text { project } \\
\text { outcomes }\end{array}$ & $\begin{array}{l}\text { Task/s } \\
\text { owner }\end{array}$ & $\begin{array}{l}\text { A person } \\
\text { respon- } \\
\text { sible for } \\
\text { itera- } \\
\text { tion/s }\end{array}$ & $\begin{array}{l}\text { Agile man- } \\
\text { agement } \\
\text { master/ } \\
\text { specialist }\end{array}$ & $\begin{array}{l}\text { Ordinary } \\
\text { team } \\
\text { mem- } \\
\text { bers }\end{array}$ \\
\hline $\begin{array}{l}\text { Introducing the } \\
\text { project launch } \\
\text { document to } \\
\text { the team }\end{array}$ & $I^{*}$ & & Inf & Inf & Inf & Inf \\
\hline $\begin{array}{l}\text { Formulating } \\
\text { project tasks } \\
\text { and iterations }\end{array}$ & $M D$ & Inf & $P / I$ & $\mathrm{P} / \mathrm{I}$ & $P / I$ & $\mathrm{P} / \mathrm{I}$ \\
\hline $\begin{array}{l}\text { Defining an in- } \\
\text { dicative time- } \\
\text { line for the } \\
\text { execution of } \\
\text { each iteration } \\
\text { and each task }\end{array}$ & C & & $M D$ & $M D$ & Inf & $\mathrm{P} / \mathrm{I}$ \\
\hline $\begin{array}{l}\text { Defining pro- } \\
\text { gress indica- } \\
\text { tors for individ- } \\
\text { ual tasks }\end{array}$ & C & & $M D$ & $\mathrm{P} / \mathrm{I}$ & Inf & $\mathrm{P} / \mathrm{I}$ \\
\hline Prioritizing tasks & $M D$ & & $\mathrm{P} / \mathrm{I}$ & $P$ & $\mathrm{P} / \mathrm{C}$ & $P$ \\
\hline $\begin{array}{l}\text { Assigning pri- } \\
\text { ority iterations }\end{array}$ & C & & $M D$ & $\mathrm{P} / \mathrm{I}$ & Inf & I \\
\hline $\begin{array}{l}\text { Iteration exe- } \\
\text { cution }\end{array}$ & $P / C$ & & $\mathrm{P}$ & I & Inf & 1 \\
\hline $\begin{array}{l}\text { Holding ongoing } \\
\text { team meetings }\end{array}$ & P/MD & & $\mathrm{P} / \mathrm{C}$ & $\mathrm{P} / \mathrm{Inf}$ & $P$ & $\mathrm{P} / \mathrm{Inf}$ \\
\hline $\begin{array}{l}\text { Checking for } \\
\text { necessary ad- } \\
\text { justment to itera- } \\
\text { tion execution }\end{array}$ & $M D$ & & C & I & Inf & $1 / \operatorname{lnf}$ \\
\hline $\begin{array}{l}\text { Regular meet- } \\
\text { ings to evalu- } \\
\text { ate progress } \\
\text { on tasks }\end{array}$ & $\operatorname{lnf} / M D$ & & $\mathrm{P} / \mathrm{I}$ & $\mathrm{P} / \mathrm{Inf}$ & $P / C$ & $\mathrm{P} / \mathrm{Inf}$ \\
\hline $\begin{array}{l}\text { Checks for } \\
\text { compliance } \\
\text { with the re- } \\
\text { quired outcome } \\
\text { of the task }\end{array}$ & $\operatorname{lnf} / M D$ & & $\mathrm{P} / \mathrm{I}$ & $\mathrm{P} / \mathrm{Inf}$ & $\mathrm{P} / \mathrm{C}$ & P/Inf \\
\hline
\end{tabular}


Agile project management in public sector methodological aspects

\begin{tabular}{|l|c|c|c|c|c|c|}
\hline Role & $\begin{array}{c}\text { Project } \\
\text { owner }\end{array}$ & $\begin{array}{c}\text { Public } \\
\text { owner of } \\
\text { project } \\
\text { outcomes }\end{array}$ & $\begin{array}{c}\text { Task/s } \\
\text { owner }\end{array}$ & $\begin{array}{c}\text { A person } \\
\text { respon- } \\
\text { sible for } \\
\text { itera- } \\
\text { tion/s }\end{array}$ & $\begin{array}{c}\text { Agile man- } \\
\text { agement } \\
\text { master/ } \\
\text { specialist }\end{array}$ & $\begin{array}{c}\text { Ordinary } \\
\text { team } \\
\text { mem- } \\
\text { bers }\end{array}$ \\
\hline $\begin{array}{l}\text { Check whether } \\
\text { an adjustment } \\
\text { or a change in } \\
\text { the project plan } \\
\text { is acceptable }\end{array}$ & $M D$ & $\mathrm{P} / \mathrm{l}$ & $\mathrm{P} / \mathrm{Inf}$ & $\mathrm{C}$ & $\mathrm{P} / \mathrm{Inf}$ \\
\hline $\begin{array}{l}\text { Making ad- } \\
\text { justments or } \\
\text { changes in the } \\
\text { project plan }\end{array}$ & $M D$ & $\mathrm{P} / \mathrm{l}$ & $\mathrm{P} / \mathrm{l}$ & $\mathrm{C}$ & $\mathrm{P} / \mathrm{I}$ \\
\hline $\begin{array}{l}\text { Project docu- } \\
\text { mentation }\end{array}$ & $M D$ & $\mathrm{P} / \mathrm{I}$ & $\mathrm{P} / \mathrm{l}$ & $\mathrm{P} / \mathrm{l}$ & $\mathrm{C}$ & $\mathrm{Inf}$ \\
\hline $\begin{array}{l}\text { Retrospective } \\
\text { meeting }\end{array}$ & $\mathrm{Inf}$ & $\mathrm{P} / \mathrm{l}$ & $\mathrm{P} / \mathrm{l}$ & $\mathrm{P} / \mathrm{l}$ & $\mathrm{P} / \mathrm{I}$ \\
\hline
\end{tabular}

*Key: MD - makes decisions; P - participates; C - co-ordinates; I - implements; Inf - informs. Source: compiled by the authors.

Table 3

Responsibility matrix in Stage 3. Internal monitoring

\begin{tabular}{|l|c|c|c|c|c|c|}
\hline & $\begin{array}{c}\text { Project } \\
\text { owner }\end{array}$ & $\begin{array}{c}\text { Public } \\
\text { owner of } \\
\text { project } \\
\text { outcomes }\end{array}$ & $\begin{array}{c}\text { Task/s } \\
\text { owner }\end{array}$ & $\begin{array}{c}\text { A person } \\
\text { respon- } \\
\text { sible for } \\
\text { itera- } \\
\text { tion/s }\end{array}$ & $\begin{array}{c}\text { Agile man- } \\
\text { agement } \\
\text { master/ } \\
\text { specialist }\end{array}$ & $\begin{array}{c}\text { Ordinary } \\
\text { team } \\
\text { mem- } \\
\text { bers }\end{array}$ \\
\hline Project stories & Inf/MD* & & Inf & Inf & Inf/C & Inf \\
\hline $\begin{array}{l}\text { Reporting on } \\
\text { progress indi- } \\
\text { cators for indi- } \\
\text { vidual tasks }\end{array}$ & $\mathrm{C}$ & $\mathrm{Inf}$ & $\mathrm{P} / \mathrm{I}$ & $\mathrm{P} / \mathrm{Inf}$ & $\mathrm{P} / \mathrm{Inf}$ & $\mathrm{P} / \mathrm{Inf}$ \\
\hline $\begin{array}{l}\text { Conformity } \\
\text { checks }\end{array}$ & $\mathrm{MD} / \mathrm{l}$ & & $\mathrm{P} / \mathrm{I}$ & $\mathrm{P} / \mathrm{I}$ & $\mathrm{C}$ & $\mathrm{P} / \mathrm{I}$ \\
\hline $\begin{array}{l}\text { Adaptive moni- } \\
\text { toring }\end{array}$ & $\mathrm{MD}$ & & $\mathrm{P} / \mathrm{l} / \mathrm{Inf}$ & $\mathrm{P} / / / \mathrm{Inf}$ & $\mathrm{C}$ & $\mathrm{P} / \mathrm{I} / \mathrm{Inf}$ \\
\hline $\begin{array}{l}\text { Monitoring les- } \\
\text { sons }\end{array}$ & $\mathrm{MD}$ & $\mathrm{Inf}$ & $\mathrm{P} / \mathrm{Inf}$ & $\mathrm{P} / \mathrm{Inf}$ & $\mathrm{P} / \mathrm{C}$ & $\mathrm{P} / \mathrm{Inf}$ \\
\hline
\end{tabular}

*Key: MD - makes decisions; P - participates; C - co-ordinates; I - implements; Inf - informs. Source: compiled by the authors. 
ISSN 2519-4070

Stage 3. Internal monitoring is carried out in parallel with Stage 2, and the team has the autonomy to organize the technological aspects of project monitoring according to the project needs, team vision and the requirements of the financing instrument in order to provide reasonable assurance that the planned outcomes will be achieved.

Organizationally, the methodology is agile and enables teams within their competencies, organizational experience and expertise to have the autonomy to apply other stages and iterations for agile project management, taking into account its specific features.

The outcomes of implementing the concept of agile project management methodology in the public sector depend on several key conditions, namely:

1. Creating a project-oriented environment in an organization is a prerequisite for implementing the agile project management methodology in the public sector. This means that most of the workflows must be interpreted as projects, within which a qualitative result is to be achieved, i.e. to turn the organization into a result-oriented one.

2. Creating an environment for applying this methodology requires an adequate " tip tone", i.e. the management team and management positions delegate rights and responsibilities and enable independent decision-making by the teams. This condition is entirely in the context of agile project management where in businesses fully entrust projects to project management teams. Trust is key to the success of the agile methodology.

3. On the one hand, implementing the agile project management methodology in the public sector implies an organizational attitude to teamwork and a high degree of delegation. On the other hand, it allows external stakeholders to participate in the project teamwork whenever possible.

4. It may be fully or partially implemented. Full implementation is recommended in the presence of independent decision-making by the project team, the absence of restrictive requirements by the funding organization and compliance with the project-related regulatory framework. Partial implementation is recommended when any of the provisions of the methodology contradicts the requirements of the financial backing and the specifics of the project.

5. Implementation of agile project management methodology requires a willingness within the organization to innovate, make organizational change in project management, and a high degree of independent decision-making by the teams within their competencies. Organizational capacity to manage and adapt to change is needed, i.e. perceiving the organization as a flexible, adaptable and learning system made up of intelligent people.

6. A comprehensive team-based problem-solving approach that: 1) considers all members to be qualified and valuable participants in team manage- 

methodological aspects

ment; 2) relies on the collective ability of individual teams as the main mechanism for solving problems; 3 ) restricts advance planning, focusing on rapid adaptation to dynamically changing conditions.

7. Administrative practice of minimizing the document flow in accordance with the requirements of the regulatory framework, financial reporting and control bodies.

8. Operational control, oriented on results, not on work done. Determining the limits of internal and external control when establishing the order of the project.

The proposed concept of an agile project management methodology in the public sector is open, both in terms of its practical implementation and in terms of the development of science and the integration of research achievements into it. It is not perfect, but it is the first attempt to adapt the principles of agile project management in the public sector and will be subject to further research.

\section{Practical implementation}

The methodology for agile project management in the public sector is verified, both in terms of its convergence with basic concepts and formulations of standards in the field of project management, and in terms of public sector project management practices in Bulgaria. The applied methods are a comparative analysis and a case method, while the scientific exchange is carried out through expert evaluation and in-depth interviews with representatives of the Bulgarian Institute for Standardization and with officials in municipal administrations.

Within the process of verification, the hypothesis of the research team was discussed. Namely it was discussed that the agile project management methodology can contribute to greater efficiency and effectiveness of projects in public sector organizations, not only with projects funded by the EU Structural Funds but also in the implementation of internal Bulgarian project initiatives, such as the introduction of new standards, organizational changes, etc. When these activities are considered in terms of agile project management, organizations will achieve greater public service delivery, greater transparency and stakeholder satisfaction. It received its qualitative support from practitioners who identified the main problems of conventional management and outlined organizational measures to overcome them. The proposed measures are viewed in the context of the defined principles of agile project management. During the verification, adjustments were made to the methodology in order to increase its applicability in a real work environment. 
The main challenges agile project management in the public sector faces can be identified as follows:

1) Team members' knowledge and experience

When agile project management is introduced in an organization, staff are likely to have little or no experience. At the same time, it is necessary to create teams that need to work in a completely different way. This means they will be trained and/or recruited for these teams. In both cases, the HR office will have additional obligations to clarify what competencies employees need, what responsibilities they will have, what their job descriptions should be.

2) The behaviour of leaders in an organization

In traditional management, due to its hierarchical nature, the direction is well established: managers make decisions; low levels implement them and report them. Agile practices are reversing the process, although traditional managers hardly give up the right to decision-making. They instead provide conditions for the teams, not tell them what to do. This is difficult to understand and sometimes takes time.

Teams in turn also do not have the necessary attitude to make their own decisions. They wait for the managers' approval because they recognize them as the most important stakeholders. However, the latter should be the clients/users of public services. This is also difficult to understand and takes time.

\section{3) Consistency of efforts}

Applying agile methodology at a corporate level is a long-term investment. It will make a return, although not in the short run (Challenges of Agile Adoption 2015). Therefore, agile management must be gradually introduced into an administration. It is recommended to invest efforts in one team and spread the practice to other teams only if and when it is successful.

An organization should also make it possible to reconfigure processes in order to provide team autonomy, at least within certain limits. The barrier here is related to both public sector regulations and the routine accumulated in most organizations that are highly resistant to similar changes.

\section{Conclusions}

The above-mentioned prerequisites for implementing the agile project management methodology in the public sector are in fact part of the organizational culture that is critical to the success of an administration. The organizational culture of a modern administration requires the ability to adapt quickly, to have an inclination towards continuous learning, to be proactive, to be open to 

methodological aspects

collaboration, teamwork, trust and mutual support, positive energy and optimism. Thus, mature organizations effectively overcome barriers such as resistance to change, poor communication, and strong bureaucracy inherent in vertical hierarchical structures.

The above-mentioned barriers were pointed out to be an obstacle when the present project management methodology was given approbation by representatives of various regional and local public organizations, as well as by programme, project and portfolio management experts at the Bulgarian Institute for Standardization. Despite these obstacles, the overall assessment is that the methodology has huge potential for improving the efficiency and effectiveness of work.

In a broader sense, the issue of organizational maturity develops into the problem of maturity in societies. Successful implementation of the agile methodology requires motivated and constant involvement of stakeholders and, above all, citizens as users of public services - something that Bulgarian society still lacks.

In an ideal world, citizens as users of public services would be sufficiently motivated to participate actively and responsibly in processes affecting the local community development (Cooke 2018). This means being well aware of the issues at a local level and participating in the democratic process of prioritizing local needs (exercising their right to vote), as well as being objective enough to provide insight into the potential solution to these problems, and being competent enough to understand the political, regulatory and technical limitations of these decisions. In this perfect scenario, citizens would be a permanent partner of public authorities. They are the component required for the external integration of project teams.

\section{References}

1. Agile Project Management QuickStart Guide. (2014). ClydeBank Media LLC, $164 \mathrm{p}$.

2. Altukhova, N.F., Vasileva, E.V., Slavin, B.B. (2016). Concept for new approach to project management in the activitirs of public servants. Business Informatics, No. 4(38)p, DOI:10.17323/1998-0663.2016.4.60.69, pp. 60-69.

3. Beck, K. (2001). Manifesto for Agile Software Development. Agile Alliance. Retrieved from: https://pdfs.semanticscholar.org/3eda/bb96a07765704f9c6a 1a5542e39ac2df640c.pdf

4. Brechner, E. (2015). Agile Project Management with Kanban. Washington: Microsoft Press, $160 \mathrm{p}$. 
5. Challenges of Agile Adoption. (2015). Intelliware Development Inc. Retrieved from: http:/www.intelliware.com/wp-content/uploads/Challenges-of-Agile-Adoption.pdf

6. Cooke, J. L. (2018). The power of the agile business analyst: 30 surprising ways a business analyst can add value to your agile development team. Cambridgeshire, United Kingdom: IT Governance Publishing, Ely, 2nd ed., $211 \mathrm{p}$.

7. Conforto, E. C., Salum, F., Amaral, D. C., Da Silva, S. L., De Almeida, L. F. M. (2014). Can agile project management be adopted by industries other than software development? Project Management Journal, Vol. 45, No. 3, pp. 21-34.

8. Government Extension to the PMBOK® Guide Third Edition. (2006). Project Management Institute, Inc., $80 \mathrm{p}$.

9. Hass, K. B. (2007). The blending of traditional and agile project management. PM world today, Vol. 9, No. 5, pp. 1-8.

10. Kaczorowska, A. (2015). Traditional and agile project management in public sector and ICT. 2015 Federated Conference on Computer Science and Information Systems (FedCSIS), pp. 1521-1531. IEEE.

11. Karaj, A., \& Little, J. (2013, August). Transforming a Public Sector Company: From Stone Age to Agile. 2013 Agile Conference, pp. 74-81. IEEE.

12. Nuottila, J., Aaltonen, K., Kujala, J. (2016). Challenges of adopting agile methods in a public organization. International Journal of Information Systems and Project Management, Vol. 4, No. 3, pp. 65-85.

13. Owen, R., Koskela L., Henrich G., Codinhoto R. (2006). Is Agile Project Management Applicable To Construction? Proceedings 14th Annual Conference of the International Group for Lean Construction, Santiago, Chile, $57 \mathrm{p}$.

14. Parker, R., Bradley, L. (2000). Organisational culture in the public sector: evidence from six organisations. International Journal of Public Sector Management., Vol. 13, No. 2, pp. 125-141.

15. Powner, D. (2012). Software Development: Effective Practices and Federal Challenges in Applying Agile Methods. Washington, DC: United States Government Accountability Office, $39 \mathrm{p}$.

16. Pyne, L. S., Rigby, B. (2002). Implementing a project management culture in a Government organisation. Project Management Institute Annual Seminars \& Symposium, San Antonio, TX. Newtown Square, PA: Project Management Institute, $22 \mathrm{p}$.

17. Recognizing the 12 Failure Modes in Agile Transformation. (2017). CA Technologies. Retrieved from: https://docs.broadcom.com/docs-and-downloads/ content/dam/ca/us/files/ebook/recognizing-the-twelve-failure-modes-in-agiletransformation.pdf 

methodological aspects

18. Ribeiro, A., Domingues, L. (2018). Acceptance of an agile methodology in the public sector. Procedia computer science, No. 138, pp. 621-629.

19. Roses, L. K., Windmöller, A., Carmo, E. A. D. (2016). Favorability conditions in the adoption of agile method practices for Software development in a public banking. JISTEM-Journal of Information Systems and Technology Management, Vol. 13, No. 3, pp. 439-458.

20. Schwaber, K. (2004). Agile project management with Scrum. Redmond: Microsoft Press, $192 \mathrm{p}$.

21. Skorková, Z. (2016). Competency models in public sector. Procedia-Social and Behavioral Sciences, No. 230, pp. 226-234.

22. Sutherland, J., Sutherland, J. J. (2014). Scrum: the art of doing twice the work in half the time. Currency, $256 \mathrm{p}$.

23. Taymor, E. (2017). Agile Handbook. Philosophie. Retrieved from: http://teaching.csse.uwa.edu.au/units/CITS5551/readings/agile-handbook.pdf

24. Torrecilla-Salinas, C. J., Sedeño J., Escalona M. J., Mejías M. (2013). Agile in Public Administration: Oxymoron or reality? An experience report. CEUR Workshop Proceedings, Vol. 1017, pp. 1-8.

25. The Five Steps of Lean Implementation. (2019). Lean Enterprise Institute. Retrieved from: https://www.lean.org/WhoWeAre/LEINewsStory.cfm?News Articleld $=17$

26. Wisitpongphan, N., Khampachua, T. (2016). Agile in public sector: Case study of dairy farm management projects. 2016 13th International Joint Conference on Computer Science and Software Engineering (JCSSE), pp. 1-5. IEEE. 